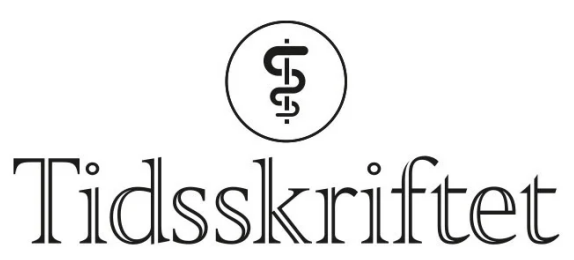

DEN NORSKE LEGEFORENING

\title{
Rettelse: En kvinne i 50-årene med langvarig muskelsvakhet
}

RETTELSE

CECILIE F. RUSTAD

KRISTIAN TVETEN

GEIR J. BRAATHEN

ELSE MERCKOLL

EVA KIRKHUS

HANNE LUDT FOSSMO

KRISTIN ØRSTAVIK

Tidsskr Nor Legeforen 2022; 142: 52-5.

I Tidsskriftet nr. 1/2022, skal det på side 53 stå: Det kan være variasjon i hvordan en sykdomsgivende variant i COL6A1-genet kommer til uttrykk klinisk, selv innenfor samme familie (11).

Vi beklager feilen, den er rettet på nett.

Publisert: 18. januar 2022. Tidsskr Nor Legeforen. DOI: 10.4045/tidsskr.22.0032

(C) Tidsskrift for Den norske legeforening 2023. Lastet ned fra tidsskriftet.no 26. april 2023. 